1 School of Biosciences, The University of Birmingham, Edgbaston, Birmingham B15 2TT, UK

2 Research and Technology, BNFL, Springfields Works, Preston PR4 OXJ, UK

\section{Enzymically mediated bioprecipitation of uranium by a Citrobacter sp.: a concerted role for exocellular lipopolysaccharide and associated phosphatase in biomineral formation}

\author{
Lynne E. Macaskie, ${ }^{1}$ Karen M. Bonthrone, ${ }^{1}$ Ping Yong ${ }^{1}$ \\ and David T. Goddard ${ }^{2}$
}

\begin{abstract}
Author for correspondence: Lynne E. Macaskie. Tel: +44 121414 5889. Fax: + 441214146557.
\end{abstract} e-mail : l.e.macaskie $@$ bham.ac.uk

A Citrobacter sp. accumulated uranyl ion $\left(\mathrm{UO}_{2}^{2+}\right)$ via precipitation with phosphate ligand liberated by phosphatase activity. The onset and rate of uranyl phosphate deposition were promoted by $\mathrm{NH}_{4}^{+}$, forming $\mathrm{NH}_{4} \mathrm{UO}_{2} \mathrm{PO}_{4}$, which has a lower solubility product than $\mathrm{NaUO}_{2} \mathrm{PO}_{4}$. This acceleration decoupled the rate-limiting chemical crystallization process from the biochemical phosphate ligand generation. This provided a novel approach to monitor the cell-surface-associated changes using atomic-force microscopy in conjunction with transmission electron microscopy and electron-probe X-ray microanalysis, to visualize deposition of uranyl phosphate at the cell surface. Analysis of extracted surface materials by ${ }^{31} \mathrm{P}$ NMR spectroscopy showed phosphorus resonances at chemical shifts of 0.3 and 2.0 p.p.m., consistent with monophosphate groups of the lipid A backbone of the lipopolysaccharide (LPS). Addition of $\mathrm{UO}_{2}^{2+}$ to the extract gave a yellow precipitate which contained uranyl phosphate, while addition of $\mathrm{Cd}^{2+}$ gave a chemical shift of both resonances to a single new resonance at 3 p.p.m. Acid-phosphatasemediated crystal growth exocellularly was suggested by the presence of acid phosphatase, localized by immunogold labelling, on the outer membrane and on material exuded from the cells. Metal deposition is proposed to occur via an initial nucleation with phosphate groups localized within the LPS, shown by other workers to be produced exocellularly in association with phosphatase. The crystals are further consolidated with additional, enzymically generated phosphate in close juxtaposition, giving high loads of LPS-bound uranyl phosphate without loss of activity and distinguishing this from simple biosorption, or periplasmic or cellular metal accumulation mechanisms. Accumulation of 'tethered' metal phosphate within the LPS is suggested to prevent fouling of the cell surface by the accumulated precipitate and localization of phosphatase exocellularly is consistent with its possible functions in homeostatis and metal resistance.

Keywords: Citrobacter, lipopolysaccharide, phosphatase, metal biomineral

\section{INTRODUCTION}

Increased legislative constraints on the control of toxic discharges have prompted consideration of alternative technologies for the remediation of contaminated wastes to levels that are difficult to achieve by standard physicochemical treatments alone, and biotechnological adjuncts have been proposed to augment or replace

Abbreviations: AFM, atomic-force microscopy; EPM, extracellular polymeric materials; EPXMA, electron-probe X-ray microanalysis; PIXE, proton-induced X-ray emission; TEM, transmission electron microscopy; XRD, X-ray powder diffraction analysis. 
traditional technologies (Volesky, 1990; Gadd, 1992). Heavy metals cannot be destroyed but only concentrated and contained in a solid form for recycling or final disposal. Here, potential is offered by micro-organisms that deposit very high masses of metals as crystalline minerals, with precipitant ligands provided via biochemical or enzymic processes. Typical ligands are sulphide, produced by dissimilatory reduction of $\mathrm{SO}_{4}^{2-}$, with precipitation of heavy metals as insoluble sulphides (White \& Gadd, 1998; White et al., 1998), and hydroxide and carbonate formed spontaneously under the locally alkaline conditions generated by the metal resistance mechanisms (i.e. cation efflux countercurrent to proton uptake) of some strains of Alcaligenes eutrophus (Mergeay et al., 1985; Diels et al., 1995).

An alternative mechanism is the coupling of a growthdecoupled, single enzymic step to metal biocrystallization. A Citrobacter sp., originally isolated from metalpolluted soil, overproduces PhoN acid phosphatase (Jeong et al., 1997, 1998; Basnakova et al., 1998a), which is also expressed by several other enterobacteria (Groisman et al., 1992; Thaller et al., 1995), and which can mediate metal uptake via enzymically liberated $\mathrm{HPO}_{4}^{2-}$ to precipitate with heavy metals as cell-bound, polycrystalline metal phosphate (Jeong et al., 1997; Basnakova et al., 1998a, b). Previous studies using electron microscopy with immunogold labelling of Citrobacter sp. phosphatase suggested involvement of the phospholipid outer and inner membrane bilayers in the formation of metal phosphate nucleation foci in juxtaposition to the periplasmically localized enzyme (Jeong et al., 1997). However, extensive mineral deposits were not seen in the periplasmic space but were visible mainly outside the cell body at high metal loadings (Jeong et al., 1997).

The present study aimed to establish the role of additional exocellular nucleation sites in metal bioprecipitation and crystal growth. A working hypothesis for the process of metal accumulation is formulated, describing this in terms of the localization of the phosphatase and the biochemical and physico-chemical features of the cellular micro-environment. A possible role for phosphatase and cell-surface components in the maintenance of cellular homeostasis is also proposed.

\section{METHODS}

Organism, phosphatase activity, enzyme purification and immunogold labelling. Citrobacter sp. N14 (NCIMB 40259, deposited under the terms of the Budapest Treaty), used under licence from Isis Innovation, Oxford, UK, was cultured (aerobically, $30^{\circ} \mathrm{C}$ ) in a glycerol/glycerol 2-phosphate-based minimal medium, harvested and washed as described previously (Jeong et al., 1997, 1998; Basnakova et al., 1998a, b). Phosphatase was purified from cell extracts as described previously (Jeong et al., 1997, 1998), and assayed by the release of $p$-nitrophenol from $p$-nitrophenyl phosphate (Jeong et al., 1997, 1998). One unit of activity is defined as that liberating $1 \mathrm{nmol}$ product $\min ^{-1}$ ( $\mathrm{mg}$ bacterial protein) ${ }^{-1}$, with protein assayed by the method of Lowry or Bradford (1976), and related to the $\mathrm{OD}_{600}$ of the bacterial suspension. Purified phosphatase (Jeong et al., 1997, 1998) was used to raise antibodies in New Zealand White rabbits, with crude antibody purified by immunoaffinity chromatography (using immobilized PhoN phosphatase) and assayed by ELISA as described previously (Jeong et al., 1997). Immunogold labelling of cell sections was as described previously (Jeong et al., 1997). Sections were stained with $0.5 \%(\mathrm{w} / \mathrm{v})$ aqueous uranyl citrate $(10-30 \mathrm{~min})$, washed with distilled water $(3 \times 1 \mathrm{~min}$ each $)$ and examined with a JEOL 1200 EX 11 transmission electron microscope (see below).

Uranium uptake by resuspended cells and examination of metal-loaded cells. Cells harvested in the mid-exponential phase $(20-40 \mathrm{ml})$ were washed twice in isotonic saline $(8.5 \mathrm{~g}$ $\mathrm{NaCl}^{-1}$ ) and resuspended $\left(\mathrm{OD}_{600} 0 \cdot 3-0 \cdot 4\right)$ in $2 \mathrm{mM}$ trisodium citrate/citric acid buffer, $\mathrm{pH} 6.9,5 \mathrm{mM}$ glycerol 2-phosphate, with uranyl nitrate to $1 \mathrm{mM}\left(30{ }^{\circ} \mathrm{C}\right)$. Timed samples $(1.25 \mathrm{ml})$ were centrifuged $\left(22^{\circ} \mathrm{C}, 5 \mathrm{~min}, 13700 \mathrm{~g}\right)$ and the supernatant assayed for residual uranyl ion using arsenazo III (Yong \& Macaskie, 1995). Uranium uptake was calculated as a percentage of bacterial dry weight $[\mathrm{mg} U$ (mg bacterial dry weight $)^{-1} \times 100$ ] using a calibration of $0.495 \mathrm{mg}$ dry weight $\mathrm{ml}^{-1}$ for 1 unit of $\mathrm{OD}_{600}$ (Yong, 1996). The U-loaded cell pellets (each equivalent to $5 \mathrm{ml}$ of culture) were washed twice in isotonic saline $\left(8.5 \mathrm{~g} \mathrm{NaCl} \mathrm{l}^{-1}\right)$ and once in water, resuspended in $0.2-0.4 \mathrm{ml}$ water, mixed and placed on a Formvar-coated electron microscope grid, air-dried overnight and examined with a JEOL 1200 EX11 electron microscope (see below), without staining. For monitoring intracellular uranium, U-loaded cells (equivalent to $5 \mathrm{ml}$ of culture) were washed as above, fixed and embedded in LR White as described previously (Jeong et al., 1997). Sections (80-100 nm) cut with a Reichert-Jung Knifemaker and a microtome (Ultracut E, Reichert-Jung) were examined without further staining. Specimens were examined using a JEOL 1200 EX11 transmission electron microscope (accelerating voltage $80 \mathrm{kV}$ ). Elemental distribution was determined by electron-probe $\mathrm{X}$-ray microanalysis (EPXMA; previously called energy-dispersive X-ray analysis, EDAX) on specimen micro areas (approx. $0 \cdot 1 \times 0 \cdot 1 \mu \mathrm{m}$ ) using a JEOL 100 CXII electron microscope (accelerating voltage $100 \mathrm{kV}$ ) fitted with a highresolution scanning attachment, LaB6 filament, $30 \mathrm{~mm} 2 \mathrm{Si}(\mathrm{Li})$ ATW detector and Oxford Instruments Link ISIS microanalysis system as described by Basnakova et al. (1998b).

To obtain complementary information, whole cells were also examined by atomic-force microscopy (AFM) at BNFL, Preston, UK, using air-dried $\left(20-25^{\circ} \mathrm{C}\right)$ mounts on glass slides of metal-loaded cells or cells not challenged with uranyl ion (controls). Specimens were examined using a NanoScope III atomic-force microscope (Digital Instruments, USA). Imaging was carried out using microfabricated $\mathrm{Si}_{3} \mathrm{~N}_{4}$ tips (nominal spring constant $0.06 \mathrm{~N} \mathrm{~m}^{-1}$, tip radius approx. $40 \mathrm{~nm}$ ) in contact mode with the interaction force minimized, as determined by reference to the force-distance curve as recommended by the manufacturer. Previous studies of biofilms using the AFM (Goddard et al., 1996) have shown that some dehydration of the bacterial cells occurs upon airdrying but the technique has potential for imaging of samples of biological origin without pre-treatment (Surman et al., 1996).

Solid-state methods of biomass examination. For confirmation of the identity of the accumulated metal phosphate, cells were also examined using proton-induced X-ray emission (PIXE) for elemental mapping of samples and high-sensitivity estimation of elemental content. This bulk technique gives an elemental ratio of the population as a whole, analysing the 
whole pellet following metal exposure. Cell pellets were washed in water, dried, ground to homogeneity, wet with acetone, then placed on a thin pioloform film on an aluminium target, and dried at room temperature. Quantitative elemental analyses were done using the Oxford Scanning Proton Microprobe (Johansson \& Campbell, 1988; Watt \& Grime, 1989; Grime \& Watt, 1990; Grime et al., 1991; Breese et al., 1992) in the Department of Nuclear Physics, University of Oxford, UK. Elemental maps were obtained of specimen areas of approximately $1-2 \mathrm{~mm} \times 1-2 \mathrm{~mm}$ held within the proton beam $(3.0 \mathrm{MeV}$ protons produced using a particle accelerator constructed in the Department of Nuclear Physics, University of Oxford). Matrix major element composition and thickness, which are needed to calculate PIXE corrections, were determined by simultaneously determined Rutherford backscattering (RBS) spectra. The accuracy of PIXE using the RBS correction was demonstrated by comparison of data obtained by PIXE with that determined by other methods (Tamana et al., 1994) and sample data were also cross-validated versus EPXMA on common sample fields of U-loaded Citrobacter to check the accuracy of the PIXE technique (Basnakova et al., 1998b).

The identity of crystalline metal deposits was further confirmed using X-ray powder diffraction analysis (XRD). Metalloaded biomass samples, ground as above, were examined using a high-precision powder diffractometer in the School of Physics, University of Birmingham (Yong \& Macaskie, 1995, 1998). Exposure times were up to $16 \mathrm{~h}$ to monochromatic $\mathrm{Cu}$ $\mathrm{K} \alpha 1$ radiation produced using an incident-beam cured-crystal germanium monochromator with asymmetric focusing at $25^{\circ} \mathrm{C}$. The scale error of $2 \theta$ was $0.007^{\circ}$ and the specimen surface displacement was $0.0305 \mathrm{~mm}$, which was checked by a standard reference material $(\mathrm{Ag})$. The powder diffraction patterns were recorded from 5 to $60^{\circ}(2 \theta)$ with a step length of $0 \cdot 05^{\circ}(2 \theta)$.

Preparation of extracellular material, and metal uptake by extracted material. Extracellular polymers were isolated by the method of Morgan et al. (1990). Cells (usually 1 litre: midto late-exponential phase) were harvested by centrifugation and the pellet was washed and resuspended in isotonic saline $(200-400 \mathrm{ml})$ and heated at $80^{\circ} \mathrm{C}(1 \mathrm{~h})$. Cells were removed by centrifugation and cooled supernatant (1 vol.) was treated with 9 vols acetone/ethanol $\left(3: 1, \mathrm{v} / \mathrm{v} ; 4^{\circ} \mathrm{C}\right.$, overnight $)$. The white solid was collected under gravity with removal of most of the clear supernatant by aspiration, and finally by centrifugation, washed with acetone and allowed to dry. Before analysis, the samples were washed repeatedly with distilled water, the precipitation step was repeated between each wash and all washings were analysed for inorganic phosphate by a modification of the method of Pierpoint (1957) as described previously (Jeong et al., 1997; Yong \& Macaskie, 1998).

Dried sample (several milligrams) was examined using PIXE (as above). Solution ${ }^{31} \mathrm{P}$ NMR spectroscopy (20-50 mg sample per tube) was done in a Brüker $400 \mathrm{MHz}$ spectrometer at $161 \mathrm{MHz}$ with a pulse time of $0.91 \mu$ s and a pulse recycle delay of $1 \mathrm{~s}$ with $85 \% \mathrm{H}_{3} \mathrm{PO}_{4}$ as the standard and $\mathrm{D}_{2} \mathrm{O}$ (in a capillary insert) as the field frequency lock. Spectra were acquired before and after metal exposure $(1 \mathrm{mM})$. Initial tests examined uranium binding to the extract but since paramagnetic ${ }^{238} \mathrm{U}$ quenches the NMR signal, tests were also done using ${ }^{112} \mathrm{Cd}^{2+}(1 \mathrm{mM})$, which is NMR 'silent'. For metaluptake tests, extracted polymer $(20 \mathrm{mg})$ was placed into a $100 \mathrm{ml}$ conical flask $(20 \mathrm{ml})$ in $20 \mathrm{mM}$ MOPS-NaOH buffer $/ 1$ $\mathrm{mM}$ citrate buffer (to hold the metal in solution), $\mathrm{pH} 7 \cdot 2$, and uranyl or cadmium nitrate was added, to $1 \mathrm{mM}$. The flasks were shaken gently at $30^{\circ} \mathrm{C}(4 \mathrm{~h}$; time to saturation was determined by prior experiment) and metal-laden material was precipitated and washed as before.

\section{RESULTS AND DISCUSSION}

\section{Uranium accumulation by Citrobacter N14}

To confirm that metal uptake was consistent with previous studies, cells were allowed to accumulate uranium by resuspension in the presence of $\mathrm{UO}_{2}^{2+}$ and glycerol 2-phosphate (phosphatase substrate for hydrolysis to provide phosphate ligand). Fig. 1 shows accumulation of electron-opaque material by the cells. Metal-unchallenged cells were indistinct (Fig. 1a) but Uloaded cells had a dense electron-opaque precipitate (Fig. 1b, c). Where a field of view contained a large number of cells, these were clumped (Fig. 1c). In some cells the precipitate was apparently localized at the cell periphery, or was along one side of the cell only (Fig. 1c). Analysis of electron-opaque areas on a single cell using EPXMA gave peaks corresponding to uranium and phosphorus. Analysis of the whole population for quantitative element determination was done using PIXE. The rate of uranyl accumulation varies with the cellular phosphatase activity; therefore use of batches of cells with different phosphatase specific activities (280, 520 and 750 units) yielded corrrespondingly different uranyl loadings (approx. 50-100\%, 200\% and 300\% of the bacterial dry weight as $\mathrm{U}$ after $16-18 \mathrm{~h}$ ). The more heavily loaded cells had a molar $U: P$ ratio of $1: 1$ as reported elsewhere (Yong \& Macaskie, 1995; Basnakova et al., 1998b). Cells loaded to less than $100 \%$ of the biomass dry weight with $U$ have not been examined previously. Here, the molar $\mathrm{U}: \mathrm{P}$ ratio was less than $1: 1$ $(0.33 \pm 0.03: 1$; mean \pm SEM; $n=7)$. A high content of $\mathrm{Na}$ was also found. Taking the total $\mathrm{Na}$ content and expressing this in terms of charge equivalence with $\mathrm{UO}_{2}^{2+}$ (i.e. the total $\mathrm{Na} / 2$ ) the sum of $(\mathrm{Na} / 2)+\mathrm{U}$ was equal to the molar concentration of phosphorus $(1 \cdot 01 \pm$ $0 \cdot 06: 1 ; n=7)$. This suggests that in the early stages of bioprecipitation the deposited solid was a composite of $\mathrm{Na}_{2} \mathrm{HPO}_{4}$ and $\mathrm{HUO}_{2} \mathrm{PO}_{4}$. It could be argued that the $\mathrm{Na}$ represents 'biological' sodium, or $\mathrm{Na}$ carried over from the sample preparation (saline wash). However, parallel tests using $1 \mathrm{mM}$ yttrium gave little accumulated $\mathrm{Na}$. This is probably because $\mathrm{Y}^{3+}$ precipitates efficiently as the phosphate, with little entrapment of $\mathrm{Na}$ (the rate of removal of $\mathrm{Y}^{3+}$ was fivefold greater than that of $\mathrm{UO}_{2}^{2+}$ ), and the molar $\mathrm{Y}: \mathrm{P}$ ratio in the precipitate was $1.28 \pm$ $0 \cdot 15: 1$ (mean \pm SEM $; n=7$ ).

XRD was used to examine the crystallinity of the cellbound uranyl phosphate. The lightly loaded cells (50-100\% of the biomass dry weight as U) gave a spectrum of relatively low crystallinity (broad peaks), with the nearest match identified as uranyl oxonium phosphate hydrate (Fig. 2a); the match to the reference spectrum of hydrogen uranyl phosphate (Fig. 2b, vertical lines) was weaker. The more heavily loaded cells (200-300\% of the biomass dry weight as U) gave a spectrum clearly identifiable as $\mathrm{HUO}_{2} \mathrm{PO}_{4} \cdot 4 \mathrm{H}_{2} \mathrm{O}$ (Fig. 

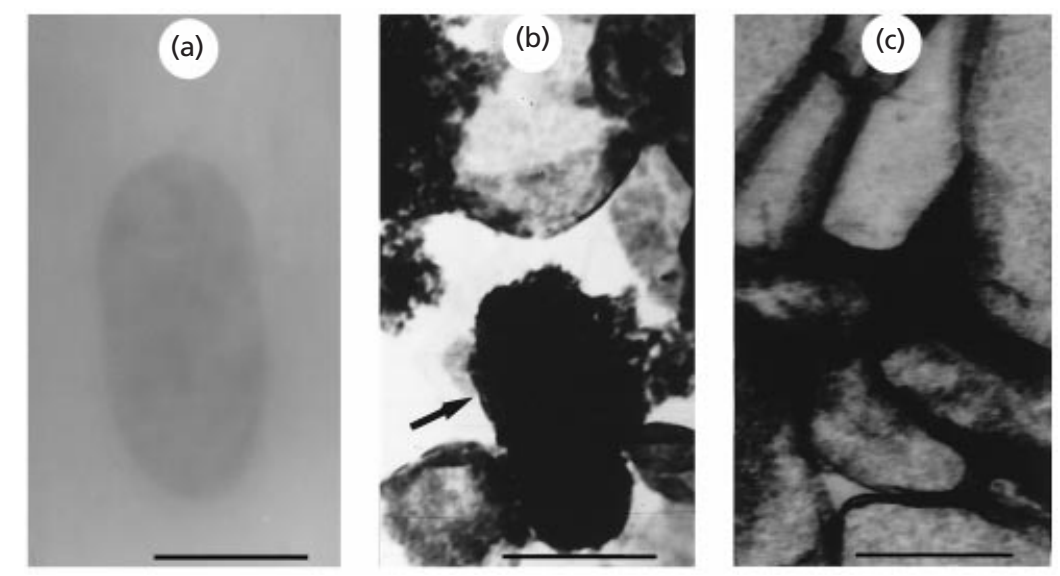

Fig. 1. Uranyl ion accumulation by Citrobacter N14. Cells were grown in minimal medium and subsequently challenged with $\mathrm{UO}_{2}^{2+}$ as described in Methods. The incubation was interrupted by harvesting the cells at appropriate times to give the uranyl loadings as specified. (a) Cell from a uranylunchallenged preparation (control). (b) As (a), except that this cell (arrowed) was from a preparation that was loaded with uranyl ion to approximately $300 \%$ of the bacterial dry weight. (c) As (b), except that the cells were loaded with uranyl ion to approximately $200 \%$ of the bacterial dry weight and are clumped. Bars, $1 \mu \mathrm{m}$.
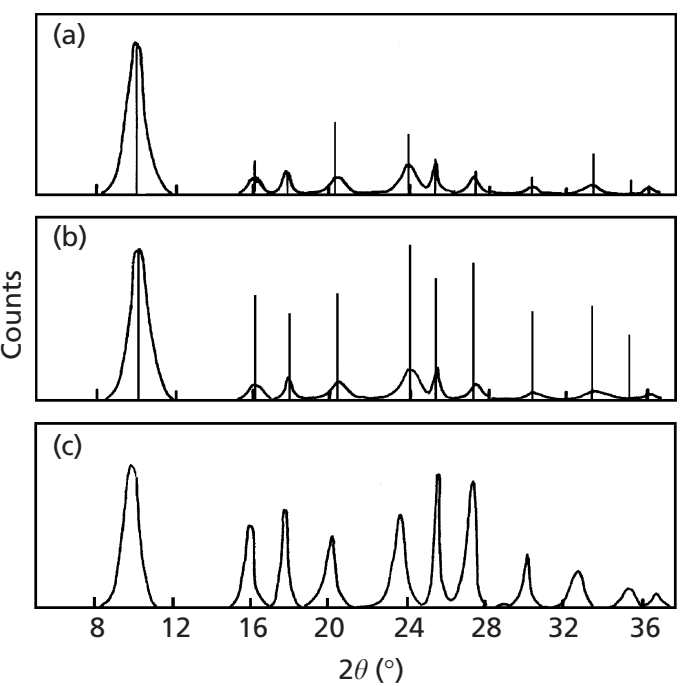

Fig. 2. (a, b) X-ray spectra (acquired overnight) of dried cells that had been loaded with $U$ to $50-100 \%$ of the biomass dry weight, and comparison with reference databases (vertical lines) for uranyl oxonium hydrate, $\mathrm{H}_{3} \mathrm{OUO}_{2} \mathrm{PO}_{4} \cdot 3 \mathrm{H}_{2} \mathrm{O}$ (a) and hydrogen uranyl phosphate, $\mathrm{HUO}_{2} \mathrm{PO}_{4} \cdot 4 \mathrm{H}_{2} \mathrm{O}$ (b). (c) The corresponding spectrum for cells loaded to $200-300 \%$ of the biomass dry weight as $\mathrm{U}$.

2c). Taken together, the data could suggest that initially some hydrogen uranyl phosphate is formed, together with the complex of $\mathrm{Na}_{2} \mathrm{HPO}_{4}$ (the $\mathrm{Na}$ would come from the use of the disodium salt of glycerol 2-phosphate as substrate), entrapping this within the developing crystal. Subsequent crystal development would involve loss of the $\mathrm{Na}_{2} \mathrm{HPO}_{4}$ components and dehydration to give the spectrum shown in Fig. 2(c) and as reported previously for heavily loaded cells (Yong \& Macaskie, 1995; Bonthrone et al., 1996). In fact, the likely composition of the crystal is $\mathrm{NaUO}_{2} \mathrm{PO}_{4}$; it is not possible to differentiate between $\mathrm{NaUO}_{2} \mathrm{PO}_{4}$ or $\mathrm{HUO}_{2} \mathrm{PO}_{4}$ by XRD but the solubility product of the former is several orders of magnitude less (see Yong \& Macaskie, 1995).

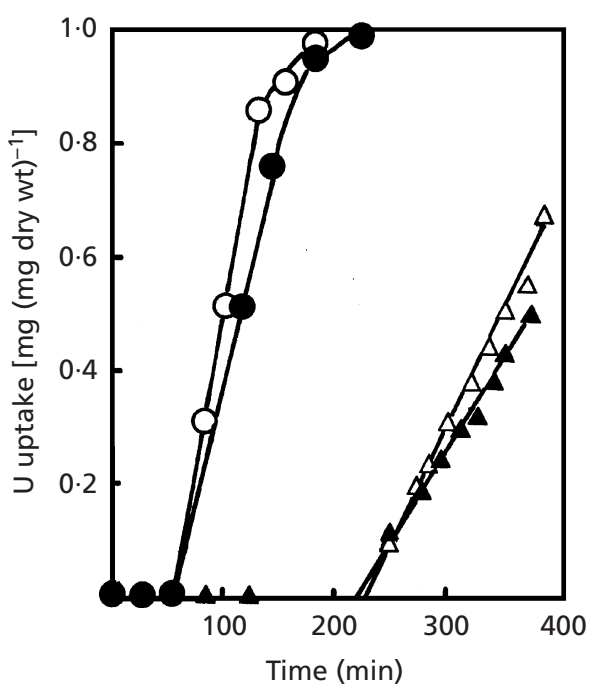

Fig. 3. Uranyl ion uptake by Citrobacter sp. N14. Cells were challenged in suspension in standard buffered uranyl solution (see Methods) in the presence of $5 \mathrm{mM}$ glycerol 2-phosphate without $(\boldsymbol{\Delta})$ or supplemented with (0) $100 \mathrm{mM}$ ammonium acetate to accelerate the onset of uranyl phosphate precipitation (see text). Open and filled symbols: two batches of cells with respective phosphatase specific activities of 524 and 504 units, and respective resuspension masses of 0.214 and $0.249 \mathrm{mg}$ dry weight $\mathrm{ml}^{-1}$. Cells were withdrawn initially, and after $4 \mathrm{~h}$ and $23 \mathrm{~h}$, for examination by AFM, and culture supernatants were assayed for residual uranyl ion.

\section{Acceleration of uranyl phosphate bioprecipitation using ammonium ion}

An objective of this study was to monitor the changes occurring at the cell surface during metal biocrystallization. One method to do this could involve the use of mutants altered in various cell surface structures. An alternative and more rapid approach is to use a common preparation of cells in which the biocrystallization process is altered in one factor which is decoupled from biochemical parameters, e.g. accelerated crystal formation. An improvement in crystallinity was achieved 

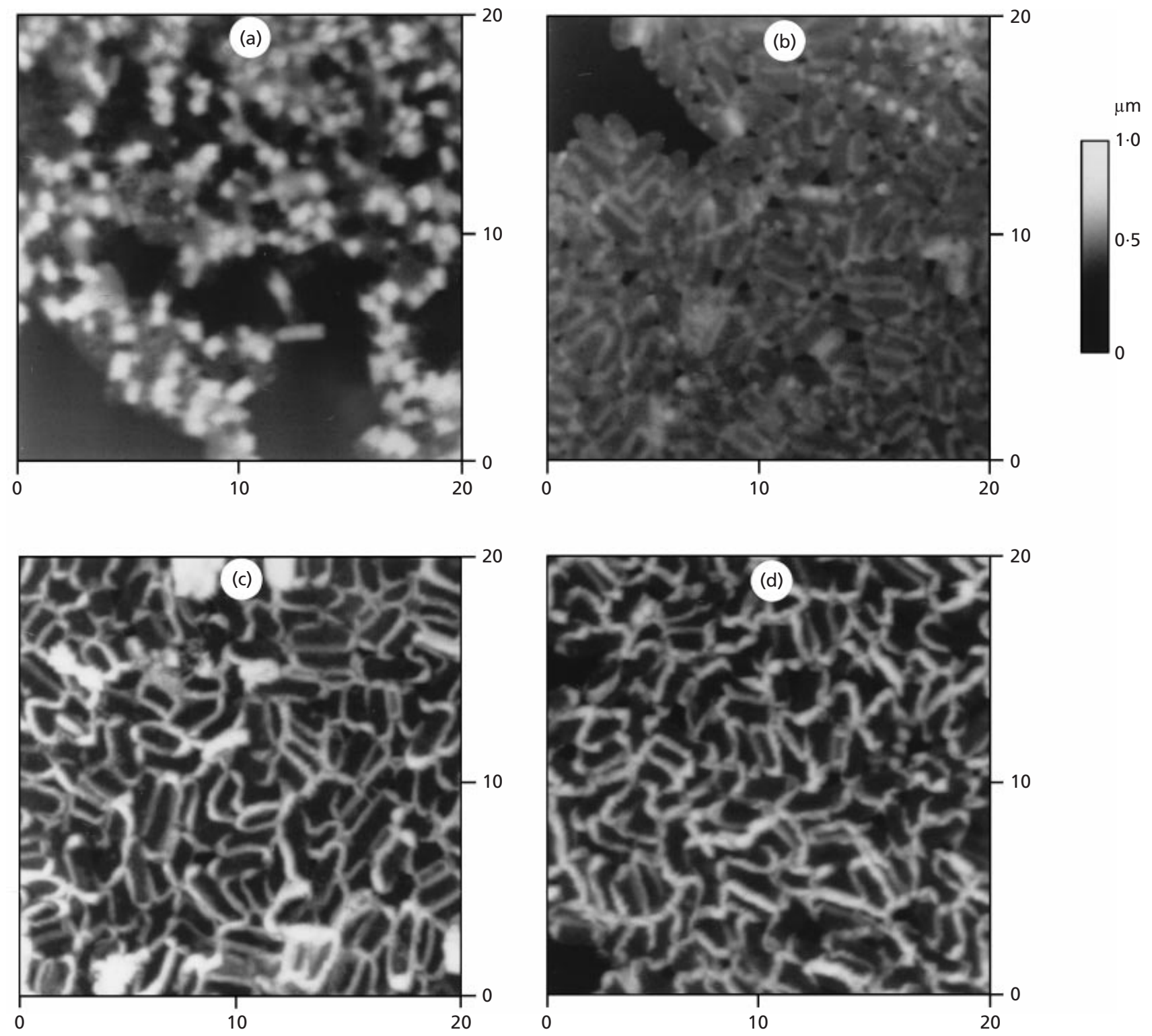

Fig. 4. Examination of uranyl-accumulating cells by AFM. Samples were withdrawn as in Fig. 3, washed briefly in water and air-dried prior to examination by AFM as described in the text. (a) Preparation before uranyl challenge or after resuspension in uranyl-free medium. (b) Sample withdrawn after $4 \mathrm{~h}$ incubation in ammonium-unsupplemented medium (uranium loading was $<10 \%$ of the bacterial dry weight: see Fig. 3). (c) As (b) but after $23 \mathrm{~h}$ of uranyl exposure. (d) Sample withdrawn after $4 \mathrm{~h}$ suspension in the presence of uranyl ion and $100 \mathrm{mM} \mathrm{NH}_{4}^{+}$(uranium loading was $>100 \%$ of the bacterial dry weight: see Fig. 3). The scale is in $\mu \mathrm{m}$ in the $x$ and $y$ dimensions (shown on the main panel) and in the $z$ dimension (shown on the small panel to the right).

over time (see above; Fig. 2) but it could be argued that in this case toxic effects on the cells over the 16-18 h incubation period may introduce additional responses (e.g. production of more extracellular polymeric materials - EPM - as a detoxification response, or EPM of a different composition; the role of bacterial exopolymer in metal resistance was described previously: Bitton \& Friehofer, 1978). It was therefore necessary to decouple crystal formation from the incubation time to rule out time-dependent effects on the cells. The onset of $\mathrm{U}$ uptake per se was slow but the onset and rate of uranyl removal were accelerated by the use of $\mathrm{NH}_{4}^{+}$(Fig. 3 ), leading to the formation of $\mathrm{NH}_{4} \mathrm{UO}_{2} \mathrm{PO}_{4}$, which has a solubility product three orders of magnitude less than the alkali metal uranyl phosphates and 16 orders of magnitude less than $\mathrm{HUO}_{2} \mathrm{PO}_{4}$ (see Yong \& Macaskie, 1995). Using the effect of $\mathrm{NH}_{4}^{+}$supplementation, two conditions were established: cells (without $\mathrm{NH}_{4}^{+}$supplementation) which had accumulated approximately $10 \%$ of their dry weight as uranium after $4 \mathrm{~h}$, and comparable $\left(\mathrm{NH}_{4}^{+}\right.$-supplemented) cells which had approximately $110 \%$ of the dry weight as $U(100 \%$ of 


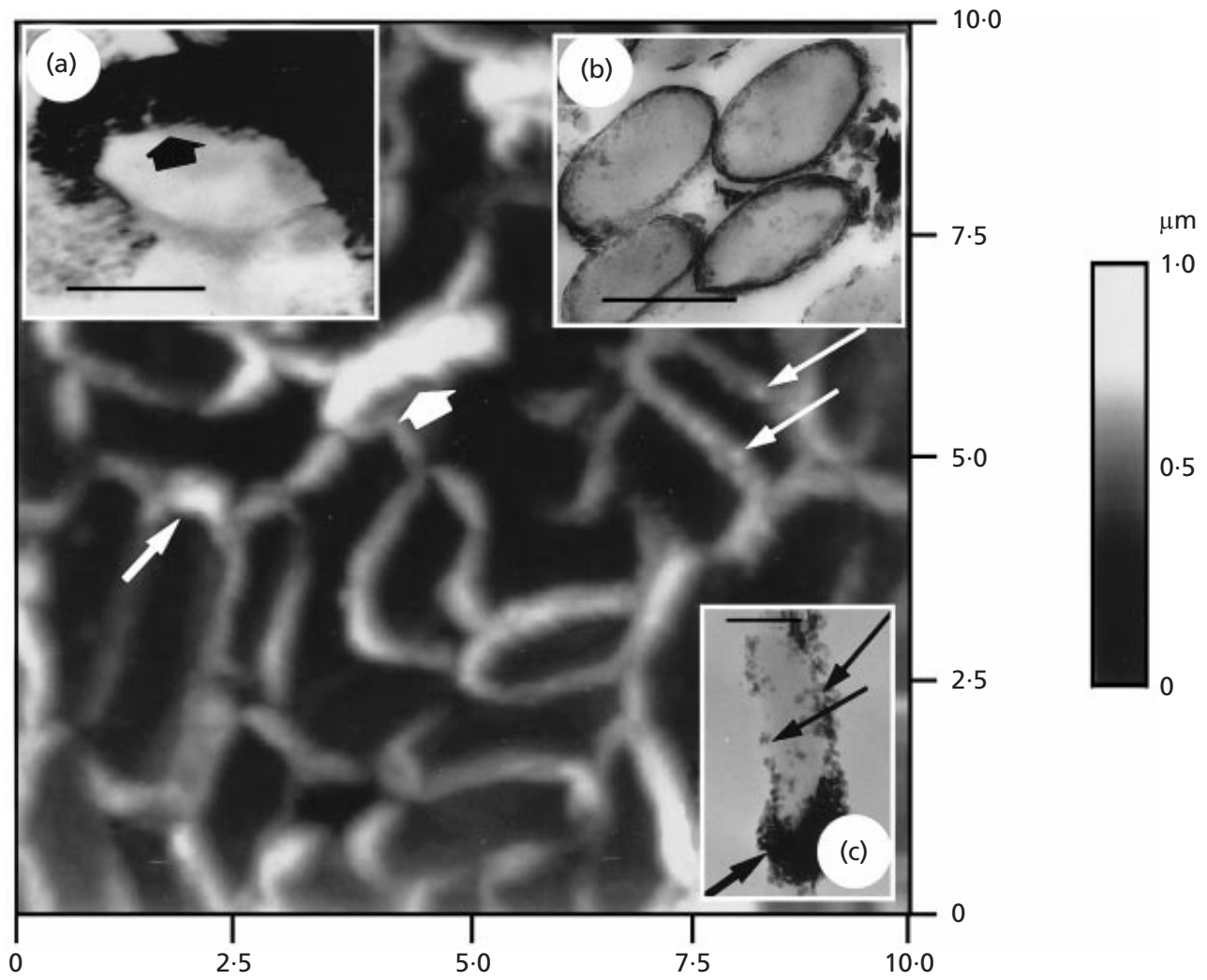

Fig. 5. AFM study of cells loaded with uranyl ion to $>100 \%$ of the bacterial dry weight (main panel) and corresponding transmission electron micrographs (insets $a, b, c)$. Cells were allowed to accumulate uranyl ion as in Fig. 3 and were airdried, unfixed and unstained. Main panel: AFM study of Citrobacter with accumulated uranyl ion to $>100 \%$ of the bacterial dry weight. The scale is in $\mu \mathrm{m}$ in the $x$ and $y$ dimensions (shown on the main panel) and in the $z$ dimension (shown on the small panel to the right). (a) TEM showing accumulation of uranyl ion to approximately $155 \%$ of the bacterial dry weight in a preparation of phosphatase specific activity of 130 units. Electron-opaque wall material is confined to one side of the cell; note similarity to adjacent cell in main figure, by AFM (thick arrows). Bar, $1 \mu \mathrm{m}$. (b) TEM of a cell section showing the surface localization of the crystalline deposit. Bar, $0.5 \mu \mathrm{m}$. A more comprehensive electron microscopic study of the surface deposition of uranyl phosphate was reported previously (Jeong et al., 1997). Note that in some cells (AFM: main figure) the wall material is not uniform, showing areas of increased height as precipitation foci or a polar concentration of precipitate (arrows). (c) Similar features shown in TEM of a single cell. Bar, $0.5 \mu \mathrm{m}$.

the uranium was removed from solution: total biomass per $20 \mathrm{ml}$ incubation was $4.3 \mathrm{mg}$; total uranium lost from $20 \mathrm{ml}$ of solution was $4.8 \mathrm{mg}$ ). In this way the chemical crystallization process was decoupled from the biochemical factors, and also those attributable to drying of the sample. With ammonium ion present the XRD pattern was as shown in Fig. 2(c), i.e. the precipitate was crystalline on the cells.

Cells incubated under the two sets of conditions were examined by AFM for morphological comparisons. It was difficult to resolve images using fresh, hydrated cells, because these moved under the probe tip. As a compromise, air-dried cells on a glass slide were used. Previous studies have established that some dehydration occurs (realistic images of cells are obtained only under hydrous conditions) but the technique is appropriate for examination of native samples (Goddard et al., 1996) and in the present study control and metal-challenged cells were dried comparably. Without $\mathrm{NH}_{4}^{+}$, little uranyl uptake occurred initially; cells changed from granular and indistinct (partially dehydrated: Fig. 4a) to faintly outlined after $4 \mathrm{~h}$ (Fig. 4b: U uptake was approximately $10 \%$ of the dry weight: see Fig. 3). In contrast to $\mathrm{NH}_{4}^{+}-$ unsupplemented cells (Fig. 4b) those with $\mathrm{NH}_{4}^{+}$had distinct cell outlines and apparently raised cell margins after $4 \mathrm{~h}$, corresponding to uranium accumulation of more than $100 \%$ of the dry weight (Fig. 4d; cf. Fig. 4b). By $23 \mathrm{~h}$ the $\mathrm{NH}_{4}^{+}$-unsupplemented cells appeared similar to their $\mathrm{NH}_{4}^{+}$-supplemented counterparts (Fig. 4c) in accordance with their similar uranium loading, which ceased due to depeletion of the solution of uranyl ion. In contrast to the changes shown in Fig. 4, control cells without uranium did not change in appearance during incubation. As an additional control, tests were done using cells challenged with $\mathrm{Pd}^{2+}$ (which is not accumulated by the Citrobacter sp.: K. M. Bonthrone \& L. E. Macaskie, unpublished); in this case no raised cell margins were visible.

After $23 \mathrm{~h}$ both sets of cells appeared to be very similar to the flocculated cells of Fig. 1(c). Some cells were 
Table 1. Elemental analysis of extracted polymeric material using PIXE

The data are means $\pm \operatorname{sem}(n=10)$.

\begin{tabular}{|lcc|}
\hline Element & Concn $\left(\boldsymbol{\mu g ~ \mathrm { g } ^ { - 1 } )}\right.$ & Molar ratio to Na \\
\hline $\mathrm{Na}$ & $2 \cdot 27 \pm 1 \cdot 76$ & $1 \cdot 0$ \\
$\mathrm{P}$ & $3 \cdot 72 \pm 0 \cdot 74$ & $1 \cdot 21 \pm 0 \cdot 10$ \\
$\mathrm{~K}$ & $0 \cdot 58 \pm 0 \cdot 39$ & $0 \cdot 15 \pm 0 \cdot 10$ \\
$\mathrm{Mg}$ & $0 \cdot 29 \pm 0 \cdot 18$ & $0 \cdot 12 \pm 0 \cdot 07$ \\
$\mathrm{Ca}$ & $0 \cdot 22 \pm 0 \cdot 11$ & $0 \cdot 06 \pm 0 \cdot 03$ \\
$\mathrm{Fe}$ & $0 \cdot 02 \pm 0 \cdot 01$ & $0 \cdot 004 \pm 0 \cdot 002$ \\
\hline
\end{tabular}

heavily encrusted, while the raised margin of others was incomplete (Fig. 4c). It was concluded that despite the possible artifacts on drying, the AFM images and electron micrographs together provide a reasonable and complementary representation of uranyl accumulation. The fate of single cells in the population was further examined. Some heterogeneity in the pattern of uranyl deposition was apparent. The formation of a heavy crystalline deposit on some cells (cf. Fig. 1c) was shown by AFM (Fig. 5, main panel; thick arrow) and by transmission electron microscopy (TEM) (Fig. 5a). Here the thick deposit was confined to one edge of the cells. The cell-surface localization of the precipitate was confirmed by examination of cell sections by TEM (Fig. $5 \mathrm{~b}$ ), in accordance with a previous study (Jeong et al., 1997). Some cells had heavier deposits at the polar region (Fig. 5c and main panel, single arrow), in accordance with the greater amount of phosphatase localized at the cell poles in some cases (Jeong et al., 1997) and identified as cell-bound uranyl phosphate by EXPMA. This was seen in one cell in the sample field (Fig. 5, single arrow) and in addition the cell shown in Fig. 5(c) had peripheral nucleation foci (double arrows), seen also in some cells by AFM (Fig. 5, main panel, double arrows).

The electron microscopy and AFM studies, although essentially qualitative in nature, suggest that the site of uranyl phosphate deposition is the cell wall materials (i.e. outer membrane, lipopolysaccharide - LPS - and possibly also extracellular polysaccharidic materials), in addition to the outer-membrane localization reported by Jeong et al. (1997). In the previous study, although an initial uranyl phosphate deposition was noted on the inner and outer membrane surfaces and at high loadings uranium was present in the wall layers, the type of material laid down at the cell surface, and the mechanism of exocellular uranyl phosphate deposition following the initial nucleation, were not investigated. The previous study showed only that phosphatase activity was contributory: a phosphatase-deficient strain accumulated negligible uranium (Jeong et al., 1997), while a recombinant strain of Escherichia coli containing cloned $p h o N$ acquired the ability to accumulate uranyl phosphate (Basnakova et al., 1998a).
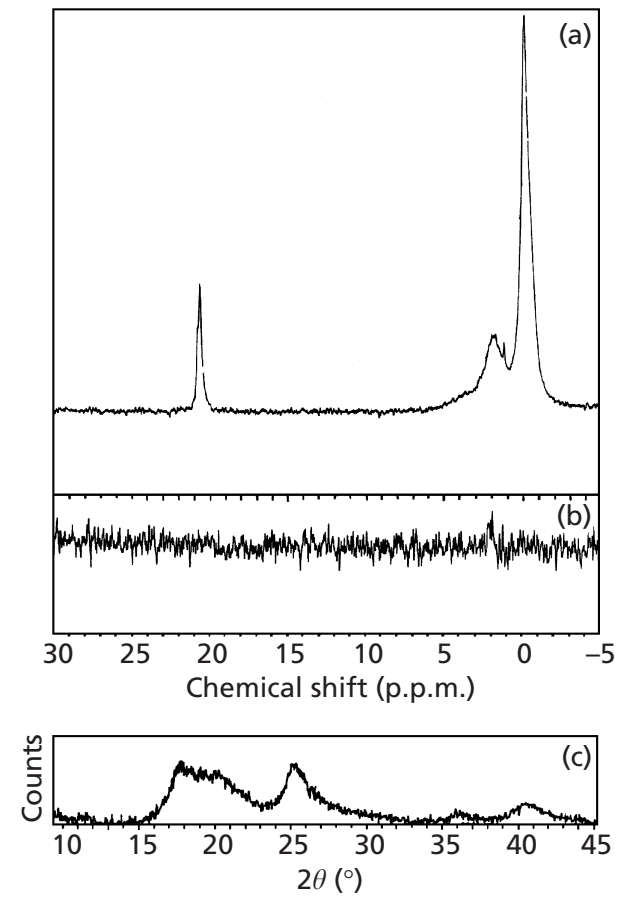

Fig. 6. ${ }^{31} \mathrm{P}$ NMR spectra of extracted material before and after challenge with uranium. (a) Solution ${ }^{31} \mathrm{P}$ NMR spectrum of extract from Citrobacter N14. (b) As (a), but with uranyl ion. Note loss of the solution ${ }^{31} \mathrm{P}$ signal. (c) XRD analysis of the yellow precipitate formed in (b). The spectrum was assigned to $\mathrm{HUO}_{2} \mathrm{PO}_{4}$ by data fitting.

\section{Further studies on the mechanism of exocellular uranyl phosphate accumulation}

A technique developed for extraction of EPM (Morgan et al., 1990) was used to obtain EPM and other loosely bound, polymeric material as a white precipitate. No further purification was attempted. This material contained a substantial amount of phosphorus, as determined by analysis of repeatedly washed, dried samples using PIXE $\left(3.7 \mu \mathrm{g} \mathrm{P} \mathrm{m}^{-1}\right.$ : Table 1$)$. The major counterion was $\mathrm{Na}^{+}$, approximately equimolar to the concentration of phosphate. No detectable phosphate was produced in the washings and it was concluded that the extracted material contained bound phosphate species, as confirmed by the ${ }^{31} \mathrm{P}$ NMR spectrum (Fig. 6a). Most of the phosphate was present as monophosphates (with chemical shifts of 0.3 p.p.m. and $2 \cdot 0$ p.p.m., respectively) with an additional, unassigned peak at 20.5 p.p.m. The ${ }^{31} \mathrm{P}$ spectrum in the region from -5 to 5 p.p.m. was similar to that of the LPS of an $E$. coli strain described previously (Strain et al., 1983a, b), with the 0.3 and $2 \cdot 0$ p.p.m. resonances attributed by these authors to monophosphate groups joined at 1 and 4 positions of the $\mathrm{N}$-acetylglucosamine residues of the lipid A backbone of the LPS (Strain et al., 1983a, b). The spectrum (Fig. 6a) is also very similar to the LPS from Salmonella minnesota strain R345 (Rb) (Batley et al., 1985), which is believed to produce an almost complete core oligosaccharide (Luderitz et al., 1971). We conclude 
that our preparation contained LPS, but since the recovered phosphate (Table 1 ) was tenfold less than that for pure LPS (calculated with reference to Klapcinska, 1994) the preparation was almost certainly not pure. It would have contained extracellular polysaccharidic material, and possibly also outer-membrane phospholipids. However, the latter gave a very broad ${ }^{31} \mathrm{P}$ NMR peak (25 p.p.m. to -25 p.p.m.: Burnell et al., 1980) in contrast to the sharp peaks in Fig. 6, while Ferris \& Beveridge (1984) noted that the LPS, containing substantial phosphorus, occurred in outer-membrane vesicles. It should be stressed that the present study did not aim to extract LPS quantitatively; the LPS was coextracted with other exopolymers. The preparation was not purified further for metal-binding studies using ${ }^{31} \mathrm{P}$ NMR, since the spectrum (Fig. 6a) indicated few other contaminating phosphate species and a good signal-tonoise ratio was obtained with the crude preparation.

In ${ }^{31} \mathrm{P}$ NMR the ${ }^{31} \mathrm{P}$ resonances are sensitive to the exact chemical environment (Batley et al., 1985); the exact peak positions depend upon the test conditions, and the positions and peak breadth also depend on the degree of association with metal ions. This makes comparison between studies difficult. However, metalstripped LPS gave sharp peaks which broadened and shifted downfield upon addition of $\mathrm{Ca}^{2+}, \mathrm{Cd}^{2+}$ or lanthanide metals (Strain et al., 1983a). The sharp peaks in Fig. 6(a) suggest that the LPS was obtained reasonably free of metals; this was confirmed by analysis of dried Citrobacter extract using PIXE (Table 1). If it is assumed on the basis of the relative phosphate contents (above) that approximately $10 \%$ of the solid material represents LPS, then the metal content of the LPS (assuming an even distribution of non-alkali metal cations between LPS and polysaccharidic components of the EPM) would be $\left(\mu \mathrm{g} \mathrm{mg}^{-1}\right): \mathrm{Mg}, 2 \cdot 9 ; \mathrm{Ca}, 2 \cdot 2 ; \mathrm{Fe}, 0 \cdot 2$ (from Table 1 ); these values are broadly comparable to those of $\mathrm{Mg}, 9 \cdot 4$; Ca, $1 \cdot 8 ; \mathrm{Fe}, 0 \cdot 8$ observed by Strain et al. (1983a).

\section{Metal uptake by the extracted material}

Upon addition of $\mathrm{UO}_{2}^{2+}$ to the extract the ${ }^{31} \mathrm{P}$ NMR signal disappeared immediately, corresponding to the disappearance of the phosphate groups from the liquid and into the solid state (Fig. 6b), and to the immediate appearance of a yellow precipitate at the bottom of the NMR tube. This precipitate, analysed by PIXE, had a composition of (molar ratios) $\mathrm{P}: \mathrm{Na}, 1 \cdot 1 \pm 0 \cdot 1 ; \mathrm{U}: \mathrm{Na}$, $14 \cdot 3 \pm 1 \cdot 1 \mathrm{U}: \mathrm{P}, 13 \cdot 0 \pm 2 \cdot 1$ (mean \pm SEM; $n=3$ ). Clearly the uranium loading was much greater than stoichiometric and probably represented binding of uranium also to species other than phosphate groups (the LPS was estimated to be only approx. $10 \%$ pure: see above). A correspondingly poor XRD powder pattern was obtained from the yellow precipitate (Fig. 6c) but this was similar to that of Fig. 2, after data fitting, i.e. it contained hydrogen uranyl phosphate.

It was concluded that the LPS and also other components extracted from Citrobacter N14 accumulate uranyl ion substantially but further tests were not done using $\mathrm{UO}_{2}^{2+}$
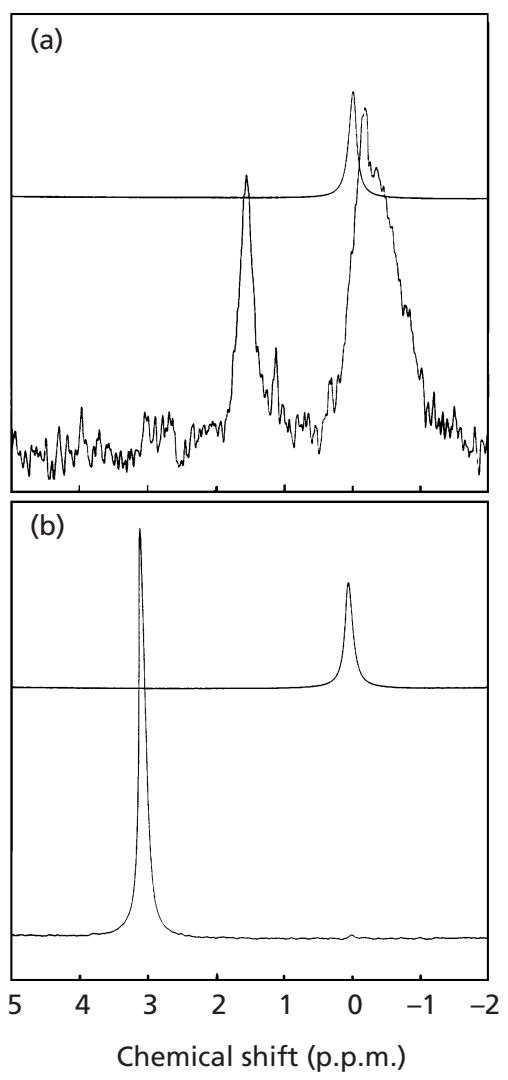

Fig. 7. ${ }^{31} \mathrm{P}$ NMR spectra of extracted material before and after challenge with cadmium. (a) Solution ${ }^{31} \mathrm{P}$ NMR spectrum of extract from Citrobacter N14. (b) As (a), but with $\mathrm{Cd}^{2+}$.

because of the quenching effects of the paramagnetic nucleus and because of the precipitation in the experiment. Instead, the diamagnetic (NMR 'silent') ${ }^{112} \mathrm{Cd}^{2+}$ was used to monitor metal uptake. In this case the resonances from 2 to -2 p.p.m. disappeared and were replaced by one new resonance, at 3 p.p.m. (Fig. 7). This is similar to that reported previously by Strain et al. (1983a) and confirms binding of metal by Citrobacter LPS. Strain et al. (1983a) noted that the exact peak positions were $\mathrm{pH}$-dependent but a common resonance of 3 p.p.m. for the two phosphate species was seen at pH 6.5. More accurate analysis was not possible in the present case. The extracted material was very viscous when dissolved in the minimum concentration of water (to obtain a good signal-to-noise ratio during examination by NMR); the exact concentration, and the $\mathrm{pH}$, were not determined. Peak positions can be affected by the $\mathrm{pH}$ and the Cd:LPS ratio used, as noted by Strain $e t$ al. (1983a). These authors also noted that, of $\mathrm{Mg}^{2+}, \mathrm{Ca}^{2+}$ and $\mathrm{Cd}^{2+}$, the last resulted by far in the largest chemical shift changes, and that the $\mathrm{p} K_{\mathrm{a}}$ values of LPS phosphate groups in the presence of $\mathrm{Cd}^{2+}$ were shifted to lower $\mathrm{pH}$ by approximately 2 units, accounting for the metal-iondependent change in the ${ }^{31} \mathrm{P}$ chemical shifts. With the paramagnetic lanthanides (Strain et al., 1983a) and with $\mathrm{Mn}^{2+}$ (Ferris \& Beveridge, 1986) the peak intensities (but not, substantially, the chemical shifts) decreased 

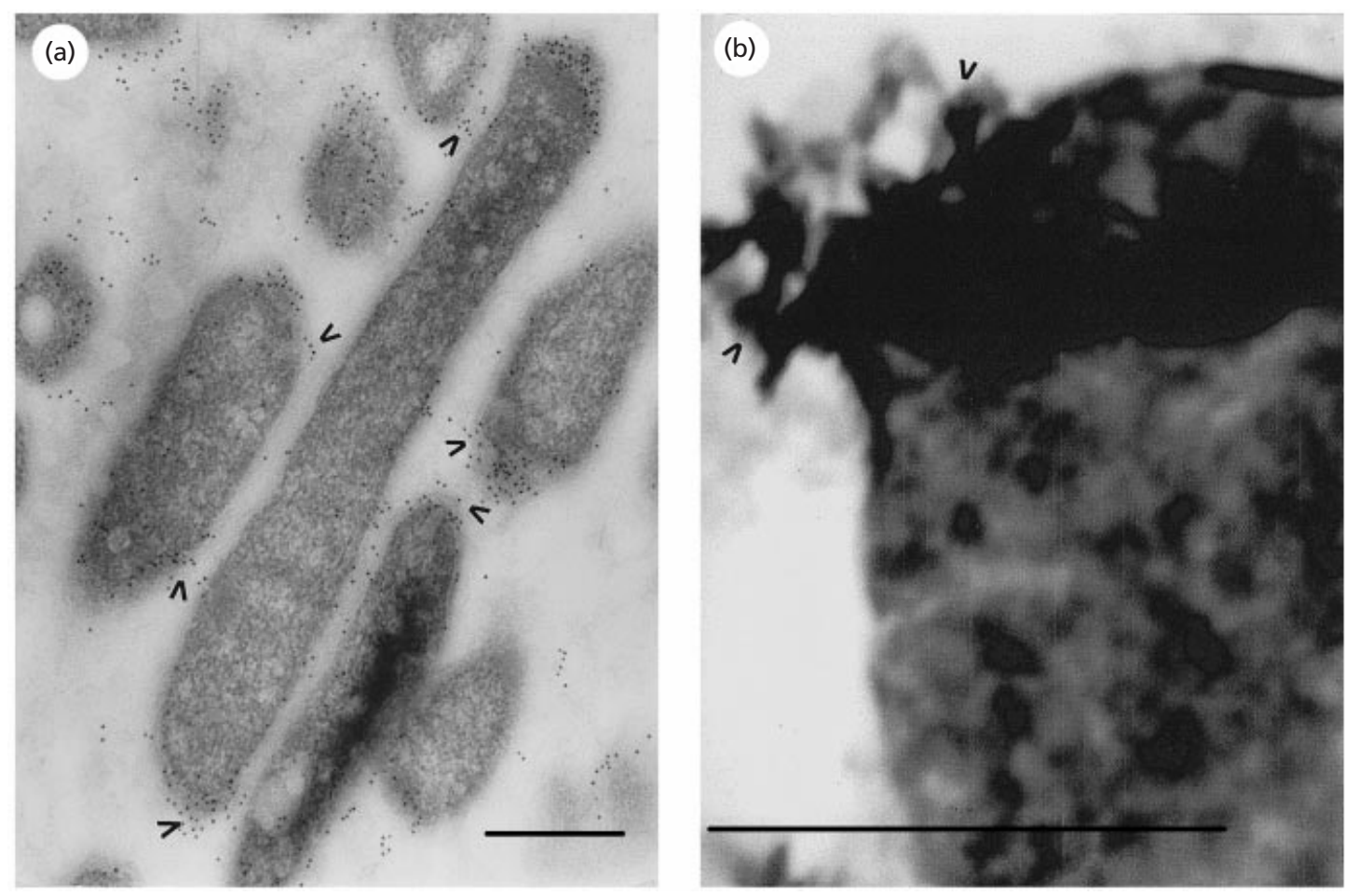

Fig. 8. Localization of phosphatase and uranyl phosphate deposition. Immunogold labelling of phosphatase was done as previously (Jeong et al., 1997); see also Methods. (a) Localization of phosphatase on and around the cells. Enzyme is visible in association with the outer membrane (arrowheads), and exocellularly. (b) Cell-surface accumulation of uranyl phosphate. Bars, $0.5 \mu \mathrm{m}$. The cells shown in these examples had a phosphatase specific activity of 670 units and were loaded with $U$ to $400 \%$ of the bacterial dry weight.

with increasing metal concentration. Our attempts to follow ${ }^{31} \mathrm{P}$ chemical shift using paramagnetic $\mathrm{UO}_{2}^{2+}$ were unsuccessful due to precipitation (above); note that in the previous work (Strain et al., 1983a; Ferris \& Beveridge, 1986) the metal was added at concentrations several orders of magnitude less than the concentration of LPS phosphorus. The present study was targeted towards high metal loading and the metal was present to excess.

In previous studies high loads of cell-bound metal phosphate were obtained (several grams of uranium per gram dry cells; e.g. Basnakova et al., 1998a) but the extracted extracellular material accumulated relatively little uranyl ion per se: e.g. to less than $5 \%$ of its dry weight as uranium; furthermore, $\mathrm{UO}_{2}^{2+}$ accumulation ceased after $4 \mathrm{~h}$ (K. M. Bonthrone \& L. E. Macaskie, unpublished). Contribution of additional inorganic phosphate via phosphatase activity is required for more extensive metal precipitation (see earlier) but expression of high levels of phosphatase alone does not confer the ability to take up uranium extensively: the PhoC phosphatase ceased to produce phosphate under conditions where PhoN did so, during uranyl exposure (Basnakova et al., 1998a), and enzyme inhibition by $\mathrm{UO}_{2}^{2+}$ was probable. However the PhoN phosphatase is also sensitive to uranyl ion (approx. $K_{\mathrm{i}} 25 \mu \mathrm{M}$ : Jeong \& Macaskie, 1995) and the enzyme is presumed, therefore, to be localized within a protective cellular environment.

\section{Requirement for cellular LPS and phosphatase for efficient metal bioprecipitation}

The present study implicates LPS as a major site of $\mathrm{UO}_{2}^{2+}$ binding and also of uranyl phosphate nucleation; therefore the localization of the Citrobacter phosphatase was re-examined from a library of electron micrographs obtained in a previous study (Jeong et al., 1997) to clarify the mechanism of metal uptake. A previous study using Pseudomonas aeruginosa has identified that exocellular membrane vesicles rich in LPS can also serve as a carrier for exocellular alkaline phosphatase; this represents a mechanism for protein export (Kadurugamuwa \& Beveridge, 1995). Fig. 8(a) shows the localization of a portion of the Citrobacter phosphatase outside the cell, either associated with outer-membrane extrusions or within an indistinct exocellular 'fuzz'. The extracellular material probably acts as a protective 'immobilizing matrix'. Examination of the surface of Citrobacter sp. following uranyl uptake shows some extruded electron-opaque material, but no structural details are apparent (Fig. 8b). Ferris \& Beveridge (1984) reported binding of metal to outer-membrane vesicles which contained LPS but the extruded material shown in Fig. 8(b) appears to have little organized structure. It is possible that extracellular vesicles may have been disrupted during sample preparation. Fixation of the cells in a polyacrylamide gel matrix and cryofixation, followed by cryo-ultramicrometry, clearly showed the 
presence of bacterial cells and extracellular granules of metal phosphate which were, in some cases, associated with the bacterial cells (Basnakova et al., 1998b).

Metal uptake was reported by LPS in membrane vesicles (Ferris \& Beveridge, 1984), while Ingram et al. (1973) suggested that secreted alkaline phosphatase was LPSassociated. Production of (alkaline) phosphatase within outer-membrane vesicles was shown previously (Nesmeyanova et al., 1991; Kadurugamuwa \& Beveridge, 1995). We take these concepts further, suggesting a bifunctional role for LPS in the enzymic removal of metal from solution via the nucleation of metal phosphate, and also as a vehicle for immobilization of the acid phosphatase. Initially metal phosphate nucleates via the phosphate groups, as concluded using ${ }^{31} \mathrm{P}$ NMR and in accordance with previous studies (Strain et al., 1983a, b; Ferris \& Beveridge, 1984, 1986). Previous studies have noted the role of cell surface materials and exopolymers in metal uptake (e.g. reviewed by Volesky, 1990), but via chemical, not enzymic, reactions and with the sorption characteristics dependent upon the functional groups responsible for the metal-ligand interactions. In the present case the LPS-metal interactions can be regarded as the metal phosphate nucleation which precedes more extensive, enzymically fed, metal uptake without which sustained metal removal is not possible. Indeed, Langley \& Beveridge (1999) concluded that carboxylic acid groups on the $\mathrm{O}$ side-chains do not contribute significantly to metal binding and, instead, hypothesized a role for the phosphate groups in mineral formation. The need for nucleation was suggested by preliminary studies which demonstrated the need for biomass 'conditioning' for expression of full metal removal but no supported explanation was given previously (Macaskie et al., 1994). The requirement for phosphatase activity was shown by poor removal of metals in the absence of phosphatase substrate (Macaskie et al., 1994), by the use of a phosphatase-deficient mutant (Jeong et al., 1997) and by the acquisition of uranyl uptake capability by $E$. coli expressing phoN (Basnakova et al., 1998a). A close association between phosphatase activity and metal nucleation sites is probably necessary (Macaskie et al., 1994), but this study provides the first evidence of how the cell surface architecture and phosphatase localization together fulfil this obligation.

The localization of the enzyme is important. Phosphatases are often held within the periplasmic space (Neu \& Heppel, 1965; Nossal \& Heppel, 1966), and immunogold labelling confirmed this (Jeong et al., 1997). The extracellular production (export) of enzymes in Gram-negative bacteria is still not completely understood, but the involvement of a secretion-coupled biosynthesis pathway has been suggested with respect to alkaline phosphatase (e.g. Nesmeyanova et al., 1994) and a secretion process via membrane vesicle production was postulated by Kadurugamuwa \& Beveridge (1995). In addition to proteolytic modification of the mature subunits in the periplasm, an export mechanism for overproduced enzyme via outer-membrane vesicles was proposed, as visualized in E. coli (Nesmeyanova et al., 1991 ) and $P$. aeruginosa (Kadurugamuwa \& Beveridge, 1995) by electron microscopy and immunogold labelling. The phosphatase activities of the overproducing E. coli (via cloning and overexpression of phoA: Nesmeyanova et al., 1991, 1994) and the naturally PhoN-overproducing Citrobacter sp. (this study) were similar. We found no direct evidence for outer membrane vesicle production per se, but possible outer membrane extrusions were visible in some cells in association with phosphatase (Fig. 8a). The extracted material for the ${ }^{31} \mathrm{P}$ NMR study was washed in acetone but stringent precautions were not taken to exclude membrane phospholipids. However the ${ }^{31} \mathrm{P}$ NMR spectrum of Fig. 6(a) shows mainly well-defined peaks assigned to monophosphate components of LPS and without the broad peaks associated with ${ }^{31} \mathrm{P}$ NMR spectra of membrane preparations (Burnell et al., 1980). In the present case, as with previous studies (see above) there is evidence for the production of phosphatase associated with a cell surface matrix of LPS. The role of exopolymeric material as an immobilizing agent for exoenzymes was reported previously (Frolund et al., 1995). A model can be developed in which the interplay of cellular and microenvironmental factors is crucial to metal biocrystallization. Uranyl ion per se is toxic to the phosphatase and occurrence of the enzyme in a "protected' environment is likely. The native enzyme is produced as a high-molecular-mass complex, as concluded from unsuccessful attempts to fractionate it using gel-filtration chromatography (Kier et al., 1977; Jeong et al., 1998), and non-migration in non-denaturing polyacrylamide gels (Jeong et al., 1998).

The model for metal biocrystallization by whole cells assumes that the initial event is the formation of a complex between the incoming metal and the monophosphate groups of the LPS. These intercept the metal and thus protect the nearby enzyme for long enough to achieve substrate cleavage and diffusion outward of liberated $\mathrm{HPO}_{4}^{2-}$. Efficient precipitation of uranyl phosphate as the sodium, and not the protonated, form is promoted by capturing the sodium associated with the polymeric material and which was also provided as the counterion with the glycerol 2-phosphate substrate. The initial complexation also forms metal phosphate nucleation sites which are further consolidated by the codeposition of more incoming metal with the outgoing phosphate, and formation of a polycrystalline material. Metal continues to diffuse inward and phosphate outward, both along a 'downhill' concentration gradient of free ions, since the precipitated metal phosphate is removed from the equilibrium. If the bound enzyme is inhibited, or incoming metal fails to be trapped, a second line of interception can be invoked by the phospholipid groups of the membrane bilayer surrounding the cells and the adjacent reservoir of periplasmic and outer-membrane-bound phosphatase (Jeong et al., 1997). Hence, there are two 'pools' of both enzyme and nucleation foci, and a dual system for biocrystallization. Two similar, but distinct, forms of the phosphatase 
were observed previously (Jeong et al., 1998). It is possible that these represent periplasmic and exocellular forms but confirmation of this awaits further study.

These concepts can explain the fulfilment of two fundamental requirements for future applications to metal waste decontamination. First, very high metal loads can be achieved without fouling by the accumulated precipitate. The architectural arrangement of LPS in native cells is difficult to study, but a meshwork of fibrils or vesicles may hold the metal phosphate crystals in an open structure that allows continued substrate access to the enzyme. Second, the presence of available phosphate groups within the LPS could provide a localized buffering function initially, supplemented by additional phosphate provided by the enzyme. The localized $\mathrm{pH}$ could be held reasonably constant irrespective of the $\mathrm{pH}$ of the bulk solution. These effects were illustrated by the ability of immobilized cells to liberate phosphate into, and remove uranyl ion from, a solution of acid mine wastewater of $\mathrm{pH} 3 \cdot 5$, at which $\mathrm{pH}$ the phosphatase activity is normally negligible (Macaskie et al., 1997). The low $\mathrm{pH}$ of (for example) acid mine drainage waters may not, therefore, prove to be too problematic.

This study was originally conceived to develop a mechanistic model to describe metal uptake in biochemical and chemical terms in order to refine the mathematical descriptions (Macaskie et al., 1995, 1997) which enable prediction of how the biocatalyst would perform in operation. However, the present findings also allow us to develop a concept of the cell surface outside the outer membrane as a functional physiological 'compartment'. In this model, phosphatase is not exported randomly but is held in association either with extracellular membrane vesicles (Nesmeyanova et al., 1991; Kadurugamuwa \& Beveridge, 1995) or with strands of LPS. In contrast to PhoA (alkaline phosphatase), which is under the control of the pho regulon and is associated with the supply of phosphate to the cells (Torriani, 1990), the role of PhoN (acid phosphatase) still remains unclear. It is upregulated by carbon (and also phosphate) starvation (Kasahara et al., 1991), by shift into anaerobiosis and by osmotic stress (Hallett et al., 1991), and is regulated via the phoP/phoQ (sensor-regulator) regulon (Groisman et al., 1989; Miller et al., 1989; Kasahara et al., 1991, 1992; Hohmann \& Miller, 1994). Stress could include low $\mathrm{pH}$ (Hohmann \& Miller, 1994). A role of the $\mathrm{pH} 2.5$ acid phosphatase was proposed in the hydrolysis of polyphosphate to generate phosphate as a buffer within the periplasm (Dassa et al., 1982) and a similar $\mathrm{pH}$ homeostatic role could be envisaged for the PhoN phosphatase exocellularly, particularly since its $\mathrm{pH}$ optimum is $7 \cdot 0$ and below (Jeong et al., 1998), and phosphatase scavenges orthophosphate from membrane phospholipids as it is released (Kadurugamuwa \& Beveridge, 1995). The concept of LPS and membrane vesicles as a functional unit in this sense may repay further study but the evidence points to a role for PhoN in the generation of phosphate buffer in the exocellular micro-environment, with metal biocrystallization as a useful side-reaction of this activity.

\section{ACKNOWLEDGEMENTS}

K.M.B, and the ${ }^{31} \mathrm{P}$ NMR and PIXE studies, were supported by the EU (Framework IV: BRITE EURAM Program; Contract no. BR2/0199C). P. Y. and the AFM studies were supported by BNFL. The authors wish to thank Dr G. Grime for the PIXE analyses and Drs C. Hawes and B. C. Jeong for the immunogold labelling data of Fig. 8(a).

\section{REFERENCES}

Basnakova, G., Stephens, E. R., Thaller, M. C., Rossolini, G. M. \& Macaskie, L. E. (1998a). The use of Escherichia coli bearing a phoN gene for the removal of uranium and nickel from aqueous flows. Appl Microbiol Biotechnol 50, 266-272.

Basnakova, G., Spencer, A. J., Palsgard, E., Grime, G. W. \& Macaskie, L. E. (1998b). Identification of the nickel uranyl phosphate deposits on Citrobacter sp. cells by electron microscopy with electron probe X-ray microanalysis and by proton induced X-ray emission analysis. Environ Sci Technol 32, 760-765.

Batley, M., Packer, N. H. \& Redmond, J. W. (1985). Analytical studies of lipopolysaccharide and its derivatives from Salmonella minnesota R 595. I. Phosphorus magnetic resonance spectra. Biochim Biophys Acta 821, 179-194.

Bitton, G. \& Friehofer, V. (1978). Influence of extracellular polysaccharides on the toxicity of copper and cadmium towards Klebsiella aerogenes. Microb Ecol 4, 119-125.

Bonthrone, K. M., Basnakova, G., Lin, F. \& Macaskie, L. E. (1996). Bioaccumulation of nickel by intercalation into polycrystalline hydrogen uranyl phosphate deposited via an enzymatic mechanism. Nat Biotechnol 14, 635-638.

Bradford, M. M. (1976). A rapid and sensitive method for the quantitation of microgram quantities of protein utilizing the principle of protein-dye binding. Anal Biochem 72, 248-254.

Breese, M. B. H., Grime, G. W. \& Watt, F. (1992). The nuclear microprobe. Annu Rev Nucl Part Sci 42, 1-38.

Burnell, E., Alphen, L. V., Verkleij, A., deKruijff, B. \& Lugtenberg, B. (1980). ${ }^{31} \mathrm{P}$ nuclear magnetic resonance and freeze-fracture electron microscopy studies on Escherichia coli. Biochim Biophys Acta 597, 518-532.

Dassa, E., Cahau, M., Desjoyau-Cherel, B. \& Boquet, P. L. (1982). The acid phosphatase with optimum $\mathrm{pH}$ of 2.5 of Escherichia coli: a physiological and biological study. J Biol Chem 257, 6669-6676.

Diels, L., Dong, Q., Van der Lelie, D., Baeyens, W. \& Mergeay, M. (1995). The $c z c$ operon of Alcaligenes eutrophus CH34: from resistance mechanism to the removal of heavy metals. $J$ Ind Microbiol 14, 142-153.

Ferris, F. G. \& Beveridge, T. J. (1984). Binding of a paramagnetic metal cation to Escherichia coli K-12 outer membrane vesicles. FEMS Microbiol Lett 24, 43-46.

Ferris, F. G. \& Beveridge, T. J. (1986). Site specificity of metallic ion binding in Escherichia coli K-12 lipopolysaccharide. Can J Microbiol 32, 52-55.

Frolund, B., Griebe, T. \& Nelson, P. H. (1995). Enzymatic activity in the activated sludge floc matrix. Appl Microbiol Biotechnol 43, 755-761.

Gadd, G. M. (1992). Microbial control of heavy metal pollution. In Microbial Control of Pollution (Society for General Micro- 
biology Symposium vol. 48), pp. 59-88. Edited by J. C. Fry and others. Cambridge: Cambridge University Press.

Goddard, D. T., Steele, A. \& Beech, I. B. (1996). Towards in-situ AFM imaging of biofilm growth on stainless steel. Scanning Microsc 10, 983-988.

Grime, G. W. \& Watt, F. (1990). Nuclear microscopy - elemental mapping using high-energy ion beam techniques. Nucl Instr Methods B50, 197-207.

Grime, G. W., Dawson, M., Marsh, M., McArthur, I. C. \& Watt, F. (1991). The Oxford submicron nuclear microscopy facility. Nucl Instr Methods B54, 52-63.

Groisman, E. A., Chiao, E., Lipps, C. J. \& Heffron, F. (1989). Salmonella typhimurium phoP virulence gene is a transcriptional regulator. Proc Natl Acad Sci U S A 86, 7077-7081.

Groisman, E. A., Saier, M. H., Jr \& Ochman, H. (1992). Horizontal transfer of a phosphatase gene as evidence for a mosaic structure of the Salmonella genome. EMBO J 11, 1309-1316.

Hallett, D. S., Clark, P. \& Macaskie, L. E. (1991). Phosphatase production by a Citrobacter sp. growing in batch culture retarded by anaerobic or osmotic stress and the effect of the osmoprotectant glycinebetaine. FEMS Microbiol Lett 78, 7-10.

Hohmann, E. L. \& Miller, S. I. (1994). The Salmonella PhoP virulence regulon. In Phosphate in Microorganisms. Cellular and Molecular Biology, pp. 120-125. Edited by A. Torriani-Gorini, E. Yagil \& S. Silver. Washington, DC: American Society for Microbiology.

Ingram, J. M. K., Cheng, K. J. \& Costerton, J. W. (1973). Alkaline phosphatase of Pseudomonas aeruginosa: the mechanism of secretion and release of the enzyme from whole cells. Can J Microbiol 19, 1407-1415.

Jeong, B. C. \& Macaskie, L. E. (1995). PhoN-type acid phosphatases of a heavy metal-accumulating Citrobacter sp.: resistance to heavy metals and affinity towards phosphomonoester substrates. FEMS Microbiol Lett 130, 211-214.

Jeong, B. C., Hawes, C., Bonthrone, K. M. \& Macaskie, L. E. (1997). Localization of enzymatically enhanced heavy metal accumulation by Citrobacter sp. and metal accumulation in vitro by liposomes containing entrapped enzyme. Microbiology 143, 2497-2507.

Jeong, B. C., Poole, P. S., Willis, A. C. \& Macaskie, L. E. (1998). Purification and chacterization of acid-type phosphatases from a heavy-metal-accumulating Citrobacter sp. Arch Microbiol 169, 166-173.

Johansson, S. A. E. \& Campbell, J. L. (1988). PIXE-a Novel Technique for Elemental Analysis. Chichester: Wiley.

Kadurugamuwa, J. L. \& Beveridge, T. J. (1995). Virulence factors are released from Pseudomonas aeruginosa in association with membrane vesicles during normal growth and exposure to gentamicin: a novel mechanism of enzyme secretion. J Bacteriol 177, 3998-4008.

Kasahara, M., Nakata, A. \& Shinagawa, H. (1991). Molecular analysis of the Salmonella typhimurium phoN gene which encodes nonspecific acid phosphatase. J Bacteriol 173, 6760-6765.

Kasahara, M., Nakata, A. \& Shinagawa, H. (1992). Molecular analysis of the E. coli phoP-phoQ operon. J Bacteriol 174, 492-498.

Kier, L. D., Weppelman, R. \& Ames, B. N. (1977). Resolution and purification of three periplasmic phosphatases of Salmonella typhimurium. J Bacteriol 130, 399-410.

Klapcinska, B. (1994). Binding of germanium and lead to Pseudomonas putida lipopolysaccharides. Can J Microbiol 40, 686-690.
Langley, S. \& Beveridge, T. J. (1999). Effect of O-side-chain lipopolysaccharide chemistry on metal binding. Appl Environ Microbiol 65, 489-498.

Luderitz, O., Westphal, O., Staub, A. M. \& Nikaido, H. (1971). In Microbial Toxins, vol. IV, pp. 145-233. Edited by G. Weinbaum, S. Kadis \& S. J. Ajl. New York: Academic Press.

Macaskie, L. E., Jeong, B. C. \& Tolley, M. R. (1994). Enzymicallyaccelerated biomineralization of heavy metals: application to the removal of americium and plutonium from aqueous flows. FEMS Microbiol Rev 14, 351-368.

Macaskie, L. E., Empson, R. M., Lin, F. \& Tolley, M. R. (1995). Enzymatically-mediated uranium accumulation and uranium recovery using a Citrobacter sp. immobilized as a biofilm within a plug-flow reactor. J Chem Technol Biotechol 63, 1-16.

Macaskie, L. E., Yong, P., Doyle, T. C., Roig, M. G., Diaz, M. \& Manzano, T. (1997). Bioremediation of uranium-bearing wastewater: biochemical and chemical factors affecting bioprocess application. Biotechnol Bioeng 53, 100-109.

Mergeay, M., Nies, D., Schlegel, H. G., Gerits, J. \& Van Gijsegen, F. (1985). Alcaligenes eutrophus $\mathrm{CH} 34$, a facultative chemolithotroph displaying plasmid bound resistance to heavy metals. $J$ Bacteriol 162, 328-334.

Miller, S. I., Kukral, A. M. \& Mekalanos, J. J. (1989). A two component regulatory system ( $p h o P$ phoQ) controls Salmonella typhimurium virulence. Proc Natl Acad Sci U S A 86, 5054-5058.

Morgan, J. W., Forster, C. F. \& Evison, L. (1990). A comparative study of the nature of biopolymers extracted from anaerobic and aerobic sludges. Water Res 24, 743-750.

Nesmeyanova, M. A., Tsfasman, I. M., Karamyshev, A. L. \& Suzina, N. E. (1991). Secretion of the overproduced periplasmic PhoA protein into the medium and accumulation of its precursor in phoA-transformed Escherichia coli strains: involvement of outer membrane vesicles. World J Microbiol Biotechnol 7, 394-406.

Nesmeyanova, M. A., Karamyshev, A. L., Kalinin, A., Tsfasman, I. M., Badyakina, A., Khmelnitsky, M., Shlyapnikov, M. \& Ksenzenko, V. (1994). Escherichia coli alkaline phosphatase biosynthesis: influence of overproduction and amino acid substitutions. In Phosphate in Microorganisms. Cellular and Molecular Biology, pp. 264-269. Edited by A. Torriani-Gorini, E. Yagil \& S. Silver. Washington, DC: American Society for Microbiology.

Neu, H. C. \& Heppel, L. A. (1965). The release of enzymes from Escherichia coli by osmotic shock and during the formation of spheroplasts. J Biol Chem 240, 3685-3692.

Nossal, N. G. \& Heppel, L. A. (1966). The release of enzymes by osmotic shock from Escherichia coli in exponential phase. J Biol Chem 241, 3055-3062.

Pierpoint, W. S. (1957). The phosphatase and metaphosphatase activities of pea extracts. Biochem J 65, 67-76.

Strain, S. M., Fesick, S. W. \& Armitage, I. M. (1983a). Structure and metal-binding properties of lipopolysaccharides from heptoseless mutants of Escherichia coli studied by ${ }^{13} \mathrm{C}$ and ${ }^{31} \mathrm{P}$ nuclear magnetic resonance. J Biol Chem 258, 13466-13477.

Strain, S. M., Fesick, S. W. \& Armitage, I. M. (1983b). Characterization of lipopolysaccharide from a heptoseless mutant of Escherichia coli by carbon 13 nuclear magnetic resonance. J Biol Chem 258, 2906-2910.

Surman, S. B., Walker, J. T., Goddard, D. T., Morton, L. G. H., Keevil, C. W., Weaver, W., Skinner, A. \& Kurtz, J. (1996). Comparison of microscope techniques for the examination of biofilms. J Microbiol Methods 25, 57-70. 
Tamana, H., Criddle, A., Grime, G. W., Vaughn, D. \& Spratt, J. (1994). Trace elements in platinum group minerals studied using nuclear microscopy. Nucl Instr Methods B9, 213-218.

Thaller, M. C., Berlutti, F., Schippa, S., lori, P., Passariello, C. \& Rossolini, G. M. (1995). Heterogenous patterns of acid phosphatase containing low-molecular-mass polypeptides in members of the family Enterobacteriaceae. Int J Syst Bacteriol 45, 255-261.

Torriani, A. (1990). From cell membrane to nucleotides: the phosphate regulon in Escherichia coli. Bioessays 12, 371-376.

Volesky, B. (1990). Biosorption of Heavy Metals. Boca Raton, FL: CRC Press.

Watt, F. \& Grime, G. W. (1989). Principles and Application of High Energy Ion Microbeams. Bristol, UK: Hilger.

White, C. \& Gadd, G. M. (1998). Accumulation and effects of cadmium on sulphate-reducing bacterial biofilms. Microbiology 144, 1407-1415.
White, C., Sharman, A. K. \& Gadd, G. M. (1998). An integrated microbial process for the bioremediation of soil contaminated with toxic metals. Nat Biotechnol 16, 572-575.

Yong, P. (1996). Investigation of heavy metal accumulation by a Citrobacter sp. PhD thesis, University of Birmingham, UK.

Yong, P. \& Macaskie, L. E. (1995). Enhancement of uranium bioaccumulation by a Citrobacter sp. via enzymically-mediated growth of polycrystalline $\mathrm{NH}_{4} \mathrm{UO}_{2} \mathrm{PO}_{4}$. J Chem Technol Biotechnol 63, 101-108.

Yong, P. \& Macaskie, L. E. (1998). Bioaccumulation of lanthanum, uranium and thorium and use of a model system to develop a method for the biologically-mediated removal of plutonium from solution. J Chem Technol Biotechnol 71, 15-26.

Received 27 July 1999; revised 31 March 2000; accepted 14 April 2000. 